\title{
FIELD EVALUATION OF SOME FABA BEAN GENOTYPES RESISTANCE TO Liriomyza trifolii (BURGESS) AND Nezara viridula L. IN NORTH DELTA \\ Khattab, M.A.; E.M.E. Khalafalla and H.M.H.Somaa \\ Plant Protection research Institute, ARC, Giza, Egypt
}

\begin{abstract}
Thirteen faba bean (Vicia faba L.) genotypes and local variety Sakha 1 were evaluated for resistance to Liriomyza trifolii (Burgess) and Nezara viridula L. under field conditions of north Delta, Kafr El- Sheikh governorate during two successive seasons;2010/11 and 2011/12.

Based on the grand mean of every insect in the two seasons, the results indicated that the highest number of L.trifolii larvae took place on genotype $\mathrm{H}-240 \mathrm{~A}$ and $\mathrm{H}-240 \mathrm{~B}$, while the least number was recorded on $\mathrm{H}-1972 \mathrm{~B}$. The genotype $\mathrm{H}-$ 1988 received the highest number of $N$. viridula, while the other genotypes exhibited low number without significant differences. According to the resistance degree to $L$. trifolii, the genotypes $\mathrm{H}-240 \mathrm{~A}$ and $\mathrm{H}-240 \mathrm{~B}$ appeared as highly susceptible, $\mathrm{H}-1970 ; \mathrm{H}-$ 1972A; H-1973; H-1988; $\mathrm{H}-1992$ and $\mathrm{H}-243$ appeared as susceptible, $\mathrm{H}-232 ; \mathrm{H}-244$ and Sakha 1 showed relatively resistant, $\mathrm{H}-230$ showed moderately resistance, while $\mathrm{H}-1972 \mathrm{~B}$ showed resistance. As for $\mathrm{N}$. viridula, the genotype $\mathrm{H}-1988$ appeared as highly susceptible; $\mathrm{H}-1970 ; \mathrm{H}-1972 \mathrm{~A} ; \mathrm{H}-1980 ; \mathrm{H}-230 ; \mathrm{H}-232 ; \mathrm{H}-240 \mathrm{~A}$ and $\mathrm{H}-243$ appeared as susceptible, $\mathrm{H}-1973 ; \mathrm{H}-1992 ; \mathrm{H}-240 B ; \mathrm{H}-244$ and Sakha1 showed relatively resistance. The rest genotypes showed moderately resistance.

Finally, it could be concluded that the genotype $\mathrm{H}-1972 \mathrm{~B}$ exhibits resistance to the two considered insects, consequently it can be involved in breeding programs as a source of resistance under north delta conditions.
\end{abstract}

\section{INTRODUCTION}

In Egypt, faba bean, Vicia faba L. is attacked by a large number of insect pests causing serious damage, among of which are the serpentine leaf miner, Liriomyza trifolii (Burgess) and the green stink bug, Nezara viridula L. (Mohamed and SIman, 2001; abdel-Galil et al., 2002; Ebadah et al., 2006; Nassef et al, 2008; Khattab et al, 2008; El-Srand, 2013 and Awadalla et al., 2013a). The females of leaf miners puncture the upper surfaces of leaves to oviposit and the hatching larvae live in mines between the two surfaces of blades, consuming the palisade tissue, consequently reduces photosynthesis and the leaflets become yellow and dry. Thus, the larvae are protected from contact insecticides (Schuster and Everett, 1983). Adults and nymphs of $N$. viridula obtain their food by puncturing the tissues of plants with their mouth parts and extracting the plant juice from the vascular system particularly the phloem vessels (Maschwitz et al., 1987 and Khattab, 2003). Also, they cause indirect damage to the plants by providing an entry sites for pathogenic and decay organisms at the feeding punctures (McPherson et al., 1993; McPherson, 1996 and Boethel et al., 2000).

Nowadays, control strategies must be developed to control these insects without using insecticides to avoid the bad effects of these 
insecticides. The use of resistant cultivars to insect species represents one of the simplest and most convenient method in insect pest control (Dent, 1991), since they spread rapidly without much extension effort (Dyck, 1974). Therefore, the present study aims to evaluate thirteen faba bean genotypes and the local variety Sakha1 for resistance to the two mentioned insects in north Delta, Kafr El- Sheikh governorate during two successive seasons;2010/11and 2011/12.

\section{MATERIALS AND METHODS}

A field experiment was conducted at Sakha Agricultural Research Station Farm, Kafr El-Sheikh during two faba bean sucessive growing seasons; 2010/11 and 2011/12. The seeds of the tested genotypes and variety Sakha1 were obtained from Food Legumes Research Section, Sakha, Agric. Res.Station. In each season, ca. half feddan was divided into 42 plots, each of $1 / 100$ feddan. The tested genotypes and the local variety were sown in the first week of November in a complete randomized block design with three replicates for each genotype. Normal agricultural practices were followed without any pesticidal treatments throughout the growing season.

To determine the population density of the leaf miners, L. trifolii, weekly sample of 30 leaflets was chosen at random from each plot representing the three levels of the plant and the same leaflets were picked up and transferred in paper bags to the laboratory for inspection. The number of larvae per leaflet was counted and recorded using sterio microscope. As for the green stink bug, N.viridula, sample of ten branches was chosen weekly at random form each plot and the numbers of adults and nymphs were directly counted in the field. The inspection began one month after sowing and continued till the end of the season. The resistance status of the tested faba bean genotypes was dependent on the mean number of each insect $(\mathrm{MN})$ and the amount of change (AC) from one susceptibility degree to another as reported by Nosser (1996).

Where:

Amount of change $(A C)=$ maximum mean number - minimum mean number

The genotype that had mean number of insects more than $M N+A C$ was considered highly susceptible (HS); between $M N$ and $M N+A C$, susceptible (S); between $\mathrm{MN}$ and $\mathrm{MN}-\mathrm{AC}$, relatively resistant(RR); between $\mathrm{MN}-\mathrm{AC}$ and MN-2AC, moderately resistant (MR) and less than $M N-2 A C$, was considered resistant $(R)$. Data obtained were statistically analyzed using Ftest and the means were compared according to Duncan's multiple range test (1955). 


\section{RESULTS AND DISCUSSION}

\section{1-Relative susceptibility of the tested faba bean genotypes to the serpentine leaf miner infestation:}

The results in Table (1) show the seasonal mean number and resistance status of faba bean genotypes to serpentine leaf miner, $L$. trifolii infestation during 2010/11 and 2011/12 seasons. In general, the population density of the insect was higher in the first season than in the second one. The mean number of the insect on the tested genotypes varied from 55.59 (genotype H-230) to 64.80 larvae/30leaflets (genotype $\mathrm{H}-1973$ ) in the first season. Regarding to the second season, genotype $\mathrm{H}-240 \mathrm{~A}$ and $\mathrm{H}-1972 \mathrm{~A}$ harbored the highest number with means of 60.06 and 57.72 larvae /30 leaflets, respectively, while the genotype $\mathrm{H}-1972 \mathrm{~B}$ received the lowest number (49.38 larvae). The other genotypes varied in their infestation by this insect.

Judging by the general mean of the two study seasons, $\mathrm{H}-240 \mathrm{~A}$ and $\mathrm{H}-240 \mathrm{~B}$ harbored the highest number $(61.83$ and 60.41 larvae /30leaflets, respectively), while genotype $\mathrm{H}-1972 \mathrm{~B}$ received the lowest number by 53.96 larvae. The rest genotypes showed variable levels of infestation without significant differences among them.

Table (1): Mean number of Liriomyza trifolii (Burgess) and resistance status of different faba bean genotypes during seasons of 2010/11 and 2011/12 at Kafr El-Sheikh region

\begin{tabular}{|c|c|c|c|c|}
\hline \multirow{2}{*}{ Genotype } & \multicolumn{3}{|c|}{ Seasonal mean no./30 leaflets } & \multirow{2}{*}{$\begin{array}{c}\text { Resistance } \\
\text { status }\end{array}$} \\
\hline & $2010 / 11$ & $2011 / 12$ & General mean & \\
\hline $\begin{array}{l}\mathrm{H}-1970 \\
\mathrm{H}-1972 \text { A } \\
\mathrm{H}-1972 \text { B } \\
\mathrm{H}-1973 \\
\mathrm{H}-1980 \\
\mathrm{H}-1988 \\
\mathrm{H}-1992 \\
\mathrm{H}-230 \\
\mathrm{H}-232 \\
\mathrm{H}-240 \text { A } \\
\mathrm{H}-240 \quad \mathrm{~B} \\
\mathrm{H}-243 \\
\mathrm{H}-244 \\
\text { Sakha1 }\end{array}$ & $\begin{array}{l}62.52 \mathrm{a} \\
60.21 \mathrm{a} \\
58.53 \mathrm{a} \\
64.80 \mathrm{a} \\
59.61 \mathrm{a} \\
61.59 \mathrm{a} \\
61.20 \mathrm{a} \\
55.59 \mathrm{a} \\
58.26 \mathrm{a} \\
63.60 \mathrm{a} \\
64.14 \mathrm{a} \\
62.13 \mathrm{a} \\
60.54 \mathrm{a} \\
57.99 \mathrm{a}\end{array}$ & $\begin{array}{c}54.57 \mathrm{abc} \\
57.72 \mathrm{a} \\
49.38 \mathrm{c} \\
50.43 \mathrm{bc} \\
54.27 \mathrm{abc} \\
55.35 \mathrm{abc} \\
54.78 \mathrm{abc} \\
54.00 \mathrm{abc} \\
55.59 \mathrm{abc} \\
60.06 \mathrm{a} \\
56.67 \mathrm{ab} \\
53.22 \mathrm{abc} \\
54.21 \mathrm{abc} \\
54.78 \mathrm{abc}\end{array}$ & $\begin{array}{c}58.55 \mathrm{ab} \\
58.97 \mathrm{ab} \\
53.96 \mathrm{~b} \\
57.62 \mathrm{ab} \\
56.94 \mathrm{ab} \\
58.47 \mathrm{ab} \\
57.99 \mathrm{ab} \\
54.80 \mathrm{ab} \\
56.93 \mathrm{ab} \\
61.83 \mathrm{a} \\
60.41 \mathrm{a} \\
57.68 \mathrm{ab} \\
57.38 \mathrm{ab} \\
56.39 \mathrm{ab}\end{array}$ & $\begin{array}{c}\text { S } \\
S \\
R \\
S \\
R R \\
S \\
S \\
\text { MR } \\
\text { RR } \\
\text { HS } \\
\text { HS } \\
\text { S } \\
\text { RR } \\
\text { RR }\end{array}$ \\
\hline $\begin{array}{l}\text { Grand mean } \\
\pm \text { SE* }^{*}\end{array}$ & $\begin{array}{r}60.77 \\
+1.51 \\
\end{array}$ & $\begin{array}{r}54.65 \\
+1.54 \\
\end{array}$ & $\begin{array}{l}57.71 \\
+1.17 \\
\end{array}$ & \\
\hline
\end{tabular}

$\mathrm{SE}^{\star}$ means standard error

$\mathrm{HS}=$ highly susceptible, $\mathrm{S}=$ susceptible, $\mathrm{RR}=$ relatively resistant, $\mathrm{MR}=$ moderately resistant, R=resistant

According to the resistance status, the tested genotypes could be divided into five groups. The genotypes $\mathrm{H}-240 \mathrm{~A}$ and $\mathrm{H}-240 \mathrm{~B}$ appeared as highly susceptible (HS), H-1970; $\mathrm{H}-1972 \mathrm{~A} ; \mathrm{H}-1973 ; \mathrm{H}-1988 ; \mathrm{H}-1992$ and $\mathrm{H}-$ 243 appeared as susceptible (S), H-232; $\mathrm{H}-244$ and Sakha 1 showed 
relatively resistant (RR), $\mathrm{H}-230$ showed moderately resistance $(M R)$, while $\mathrm{H}$ 1972B showed resistance. Statistical analysis showed insignificant differences among faba bean genotypes to leaf miner infestation in the first season, while it was significant in the second one.

Many authors reported that the faba bean varieties and breeding lines differed in its susceptibility to L.trifolii infestation under Egyptian conditions (Abdallah et al.,2000; Mohamed \& SIman,2001; Abdel-Galil et al.,2002; Edadah et al.,2006; Abdel-Samad \& Ahmed,2006; Khattab et al.,2008 and Awadalla et al,2013a).

\section{2-Relative susceptibility of the tested faba bean genotypes to the green stink bug infestation:}

The results shown in Table (2) clear the seasonal mean number and resistance status of the tested faba bean genotypes to the green stink bug, $N$. viridula during two successive growing seasons; 2010/11 and 2011/12. Generally, it was apparent that the population density of $N$. viridula was higher in the second season than in the first one. This may be due to the differences in the prevailing weather factors prevailing in both seasonsand /or existed natural enemies density as described by Wratten et al.(2007), who reported that the natural variations in the seasonal climates affect the rate of growth, reproduction and dispersal of insects and of their natural enemies.

Table (2): Mean number of Nezara viridula L. and resistance status of different faba bean genotypes during seasons of 2010/11 and 2011/12 at Kafr El-Sheikh region.

\begin{tabular}{|l|c|c|c|c|}
\hline \multirow{2}{*}{ Genotype } & \multicolumn{3}{|c|}{ Seasonal mean no./10 branches } & \multirow{2}{*}{$\begin{array}{c}\text { Resistance } \\
\text { status }\end{array}$} \\
\cline { 2 - 4 } & $\mathbf{2 0 1 0 / 1 1}$ & $\mathbf{2 0 1 1 / 1 2}$ & General mean & $\mathrm{S}$ \\
$\mathrm{H}-1970$ & $1.51 \mathrm{ab}$ & $2.19 \mathrm{~b}$ & $1.85 \mathrm{~b}$ & $\mathrm{~S}$ \\
$\mathrm{H}-1972 \mathrm{~A}$ & $1.51 \mathrm{ab}$ & $1.44 \mathrm{c}$ & $1048 \mathrm{~b}$ & $\mathrm{MR}$ \\
$\mathrm{H}-1972 \mathrm{~B}$ & $1.40 \mathrm{ab}$ & $1.50 \mathrm{bc}$ & $1.45 \mathrm{~b}$ & $\mathrm{RR}$ \\
$\mathrm{H}-1973$ & $1.60 \mathrm{ab}$ & $1.70 \mathrm{bc}$ & $1.65 \mathrm{~b}$ & $\mathrm{~S}$ \\
$\mathrm{H}-1980$ & $1.78 \mathrm{a}$ & $1.76 \mathrm{bc}$ & $1.77 \mathrm{~b}$ & $\mathrm{HS}$ \\
$\mathrm{H}-1988$ & $1.78 \mathrm{a}$ & $2.88 \mathrm{a}$ & $2.33 \mathrm{a}$ & $\mathrm{RR}$ \\
$\mathrm{H}-1992$ & $1.64 \mathrm{ab}$ & $1.70 \mathrm{bc}$ & $1.67 \mathrm{~b}$ & $\mathrm{~S}$ \\
$\mathrm{H}-230$ & $1.82 \mathrm{a}$ & $1.68 \mathrm{bc}$ & $1.75 \mathrm{~b}$ & $\mathrm{~S}$ \\
$\mathrm{H}-232$ & $1.82 \mathrm{a}$ & $1.81 \mathrm{bc}$ & $1.82 \mathrm{~b}$ & $\mathrm{~S}$ \\
$\mathrm{H}-240 \mathrm{~A}$ & $1.78 \mathrm{a}$ & $1.76 \mathrm{bc}$ & $1.77 \mathrm{~b}$ & $\mathrm{RR}$ \\
$\mathrm{H}-240 \mathrm{~B}$ & $1.24 \mathrm{~b}$ & $1.96 \mathrm{bc}$ & $1.60 \mathrm{~b}$ & $\mathrm{~S}$ \\
$\mathrm{H}-243$ & $1.86 \mathrm{a}$ & $1.63 \mathrm{bc}$ & $1.75 \mathrm{~b}$ & $\mathrm{RR}$ \\
$\mathrm{H}-244$ & $1.51 \mathrm{ab}$ & $1.92 \mathrm{bc}$ & $1.72 \mathrm{~b}$ & $\mathrm{RR}$ \\
Sakha1 & $1.57 \mathrm{ab}$ & $1.76 \mathrm{bc}$ & $1.67 \mathrm{~b}$ & \\
\hline Grand mean & 1.63 & 1.84 & 1.73 & \\
\pm SE* & \pm 0.11 & \pm 0.20 & \pm 0.12 & \\
\hline \hline
\end{tabular}

$\mathrm{SE}^{\star}$ means standard error

HS = highly susceptible, $\mathrm{S}=$ susceptible, $\mathrm{RR}=$ relatively resistant, $\mathrm{MR}=$ moderately resistant,

Statistical analysis showed significant differences among faba bean genotypes to green stink bug infestation during the two study seasons. In the first season, the genotype $\mathrm{H}-243$ harbored the highest mean number of 
insects being 1.86 insects/ 10 branches, while $\mathrm{H}-240 \mathrm{~B}$ exhibited the lowest mean number (1.24 insects). During the second season, $\mathrm{H}-1988$ harbored the highest mean number being 2.88 insects, while the genotype $\mathrm{H}-1972 \mathrm{~A}$ received the lowest mean number (1.44 insects). Based on the general mean of the two study seasons, the results revealed that the genotype $\mathrm{H}$ 1988 harbored the highest mean number of insect (2.33 insects), while the other genotypes exhibited low number mean without significant differences among them, as the mean number varied from 1.45 to 1.85 insects.

According to the resistance degree, the tested genotypes could be classified into four groups. The genotype $\mathrm{H}-1988$ appeared as highly susceptible (HS); $\mathrm{H}-1970 ; \mathrm{H}-1972 \mathrm{~A} ; \mathrm{H}-1980 ; \mathrm{H}-230 ; \mathrm{H}-232$; $\mathrm{H}-240 \mathrm{~A}$ and $\mathrm{H}-$ 243 appeared as susceptible(S), H-1973; H-1992; H-240B;H-244 and Sakha 1 showed relatively resistant (RR). The remaining genotypes showed moderately resistance (MR). However, it is an important to point out herein that the insect mean numbers must be refer to and/ or agree with the resistance degree of veach genotype. These results agree with those obatained by El-Srand, 2013 and Awadalla et al., 2013b), who reported differences in susceptibility of faba bean genotype to $N$. viridula infestation under Egyptian conditions.

However,the variations in genotypes susceptibility to insect infestation may be due to the presence of antiexnosis (non-preference) and /or antibiosis phenomena as described by Van Emden (1987), who indicated that antixenotic plants can be avoided or less colonized by pests seeking food or oviposition site. He also, described antibiosis as the position of some property by the plant, which directly or indirectly affects the perfomance of pests in term of survival, growth, development rate, fecundity, etc. Also, Metcalf and Luckmann (1975) reported that biochemical characteristics of plants affect the behavior and/or metabolism of insects, while morphological factors mostly influence the mechanisms of locomotion, feeding, oviposition, ingestion and digestion of the pest. Kumar (1984) mentioned that environmental conditions affect the ability of plants to resist pest attack in addition to fundamental physiological processes of the plant as well as the pest, thus, a variety that exhibits resistance in one locality or environment may be susceptible in another.

From the obtained results, it could be concluded that the genotype $\mathrm{H}-1972 \mathrm{~B}$ can be used as a safe tool in the integrated management of the two insects in faba bean fields under north Delta conditions because it exhibits resistance to the two considered insects. Thus, this promising genotype could be involved in breeding programs as a source of faba bean resistance to these insects.

\section{REFERENCES}

Abdallah, F.E.; S.B. Bleih; A. El-Naggar and G.N. Gamieh (2000). Susceptibility of some faba bean varieties, insecticides alternative and yield loss estimation due to Liriomyza congesta (Beck.) and Aphis craccivora Koch. Menufiya J. Agric. Res., 25(4): 217-222 
Abdel-Galil, F.A.; M.A. Amro and A. G. Ali (2002). Relative Susceptibility of certain broad bean cultivars to the dipterous leaf miner,Liriomyza trifolii (Burgess) in Northern upper Egypt. $2^{\text {nd }}$ International Conference, Plant Protection Research Institute,Cairo, Egypt, 21-24 December,521-525

Abdel-Samad, S. and M.A. Ahmed (2006). Population fluctuation of Aphis craccivora and Liriomyza trifolii and their endoparasitoides on certain faba bean varieties. Annals of Agric. Sci.(Cairo),51(2):531-540

Awadalla,S.S.; F.E.Abdallah and Nora R. El-Mashaly (2013a). Efficiency of some conventional and non-conventional insecticides on the main insect pests attacking faba bean plants. J. Plant Prot. and Path., Mansoura Univ.,4(6): 571-580

Awadalla,S.S.; F.E.Abdallah and Nora R. El-Mashaly (2013b). Influence of some varieties on the main insect pests attacking faba bean plants. J. Plant Prot. and Path., Mansoura Univ.,4(6): 581-589

Boethel, D.J.; J.S. Russin; A.T. Wier; M.B. Layton; J.S. Mink and M.L. Bod (2000). Delayed maturity associated with southern green stink bug (Heteroptera: Pentatomidae) injury at various soybean phenological stages. J. Econ. Ent., 93(3): 707-712

Dent, D. (1991). Insect Pest Management. C.A.B. International, pp.213 Duncan , D.B.(1955). Multiple range and multiple $F$ tests. Biometrics. 11: 1- 42

Dyck, V.A. (1974). Insect pest management in rice : principles and practices. Pesticides Annual. (India), pp. 69-71

Ebadah, M.A.; Y.A. Mahmoud and S.S. Moawad (2006). Susceptibility of some faba bean cultivars to field infestation with some insect pests. Res. J. of Agric. and Biol. Sci., 2 (6): 537-540

El-Srand,E.A.(2013). Integrated management of certain piercing- sucking insects on soybean and faba bean plants at Kafer El-Shiekh governorate. Ph.D. Thesis, Fac. of Agric. Tanta Univ. p 192

Khattab, M, A.A.(2003). Ecological and biological studies on the green bug, Nezara viridula L. (Pentatomidae: Hemiptera). Ph.D. Thesis, Fac.of Agric. Tanta Univ., pp.147

Khattab, M.A.; E.M.E. Khalafalla and A.M. Nassef (2008). Relative susceptibility of certain faba bean breeding lines to infestation by serpentine leaf miner Liriomyza trifollii (burgess) under field conditions in North Delta. J. Agric. Sci. Mansoura Univ., 33(12): 8957-8963

Kumar, R. (1984). Insect pest control with special reference to African Agriculture. Edward Arnold, London. P.298

Maschwitz, U.; B. Fiala and W.R. Dolling (1987). New trophobiotic symbiosis of ants with South East Asian bugs. J. Nat. Hist., 21: 1097-1107

McPherson, R.M. (1996). Relationship between soybean maturity group and the phenology and abundance stink bugs (Heteroptera: Pentatomidae): impact on yield and quality. J. Ent. Sci., 31(2): 199-208

McPherson, R.M.; G.K. Douce and R.O. Hudson (1993). Annual variation in stink bug (Heteroptera Pentatomidae) seasonal abundance and species composition in Georgia soybean and its impact on yield and quality. J. Ent. Sci., 28(1: 61-72 
Metcalf, R.L. and jW.H. Luckmann (1975). Introduction to insect pest management. New York. p.587

Mohamed, A.M. and F.A.A. SIman (2001). Susceptibility of some broad bean varieties to natural infestation with Aphis craccivora Koch. and Liriomyza trifolii (Burgess) at upper Egypt. Assiut J. of Agric. Sci., 32(1): 167-173

Nassef, A.M.; M.A.Khattab and E.M.E. Khalafalla (2008). Seasonal abundance of Liriomyza spp. and Empoasca spp. on faba bean in relation to the associated predators and prevailing weather factors in North Delta. J. Agric. Res. Kafr El-Sheikh Univ., 34 (3): 693-703

Nosser, M. A. (1996). Mechanism of resistance in bean and cowpea varieties to certain sucking insect infestation. M. Sc. Thesis, Fac. Agric. Cairo Univ., Egypt

Schuster, D.J. and P.H. Everett (1983). Response of Liriomyza trifolii (Diptera: Agromyzidae) to insecticides on tomato. J. Econ. Entomol., 76(5):1170-1174

Van Emden, H.F. (1987). Insects and secondary plant substances- an alternative viewpoint with special reference to aphids. In Biochemical Aspects of plant and Animal Co-evolution, pp.309-323.ed. by J.B. harborne. Academic Press, London

Wratten, S.D.; G.M. Gurr; J.M.Tylianakis and K.A. Robinson (2007). Cultural control. pp. 423-445. In: Van Emden, H.F. and R. Harrington. Aphids as crop pests. CAB International p. 762

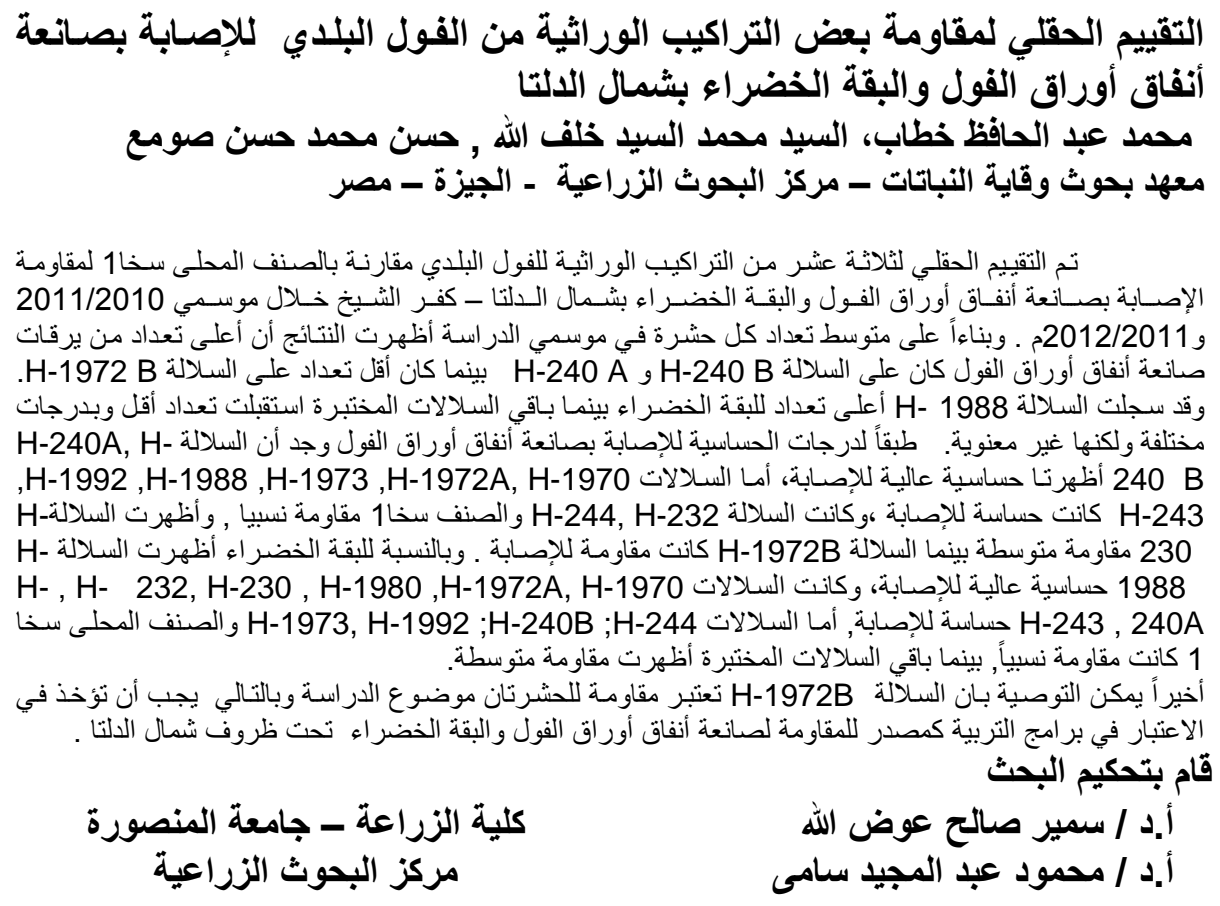


Khattab, M.A. et al. 